\title{
Comparison of the sensitivity of human embryo kidney cells, HeLa cells, and WI38 cells for the primary isolation of viruses from the eye
}

\author{
D. A. McSWIGGAN, S. DAROUGAR, A. F. M. S. RAHMAN, AND \\ JULIA A. GIBSON
}

From the Public Health Laboratory and Department of Microbiology, Central Middlesex Hospital, Londow NW10, the Virus Laboratory, Department of Clinical Ophthalmology, Institute of Ophthalmology and Moorfield Eye Hospital, London EC1, and the Public Health Laboratory, Neasden Hospital, London NW10.

SYNOPSIS A comparison has been made of the efficiency of human embryo kidney (HEK) cells? HeLa cells, and WI38 cells for the isolation of viruses from the eyes of patients suffering from acute conjunctivitis or keratoconjunctivitis. From a total of 99 specimens 21 adenoviruses (serotype $3,4,7,8$, and 13) were isolated in HEK cells, eight (serotypes 3 and 8) in HeLa cells, and four (serotype 3 ) in WI38 cells. Of the ten herpes simplex viruses isolated nine were recovered in HEK cells, seven in WI38 cells, and none in HeLa cells. The combination of HeLa cells and WI38 cells is not considered an adequate alternative to the difficult-to-obtain HEK cells for the isolation of viruses from the eye.

Conjunctivitis and keratoconjunctivitis due to herpes simplex virus and adenovirus are common in the United Kingdom and in many other developed countries. Infections due to some serotypes of the latter virus may occur in epidemic form. Definitive diagnosis of these conditions on clinical features alone may, however, be extremely difficult, especially in the early stages. For both diagnostic and epidemiological purposes isolation and identification of the causal agent is required. Therefore cell cultures used in ophthalmological practice should be especially sensitive to these two viruses.

Numerous cell systems have been used for the isolation of herpes simplex virus (Hart, Brightman, Readshaw, Porter, and Tully, 1965; Gardner, McQuillin, Black, and Richardson, 1968; White, Shew, Howsam, and Robertson, 1968) and various serotypes of adenovirus (Ward, Huebner, Rowe, Ryan, and Bell, 1955; Beale, Doane, and Ormsby, 1957; Sommerville, 1958; Bell, Martin, and Ross, 1969; Ellison, Kaufman, and Little, 1969; Wegman, Guinee, and Millian, 1970) from the eye. A pilot study in our own laboratories indicated that human embryo kidney (HEK) cells might be particularly suitable for ocular viral infections. These cells

Received for publication 19 October 1974. were found to be at least as sensitive as huma amnion cells to both herpes simplex and adenos viruses and, in our laboratory, somewhat easiesto maintain in regular supply.

The study reported here evaluates the compara tive efficiency of HEK cells, WI38 cells, and HeL cells for the isolation of viruses from the eye.

\section{Materials and Methods}

SOURCE OF SPECIMENS

The clinical specimens used in this study consiste of conjunctival material collected from the eye of patients who were referred to the External Eyd Diseases Clinic, Moorfields Eye Hospital, Londor. These patients were suffering from acute con junctivitis or keratoconjunctivitis suggesting aq infection of viral origin.

METHOD OF COLLECTION OF SPECIMENS Specimens were collected by swabbing different areas of the conjunctiva with cotton wool tipped swabs. These were placed in plastic capsules con taining 2SP transport medium with additional serun (Darougar, Jones, Kinnison, Vaughan-Jacksorn and Dunlop, 1972) and stored in a liquid nitroge refrigerator until transported to the laboratory 410 
There they were stored in a refrigerator at $-70^{\circ} \mathrm{C}$ until the time of inoculation.

\section{HUMAN EMBRYO KIDNEY CELLS}

HEK cells were grown in test tubes using Hanks' basal salt solution (HBSS) supplemented with $0.5 \%$ lactalbumin hydrolysate, $10 \%$ ox serum, and $0.03 \%$ sodium bicarbonate. The cells were maintained on Medium 199 supplemented with $0 \cdot 18 \%$ sodium bicarbonate. Both media contained penicillin, 100 units $/ \mathrm{ml}$, streptomycin, $100 \mu \mathrm{g} / \mathrm{ml}$, and polymyxin, 100 units $/ \mathrm{ml}$.

\section{HeLa CELLS}

The Virus Reference Laboratory, Colindale strain of HeLa cells was used. The cells were grown in test tubes using HBSS supplemented with $0.5 \%$ lactalbumin hydrolysate, $10 \%$ rabbit serum, $10 \%$ tryptose phosphate buffer, and $0.03 \%$ sodium bicarbonate. The cells were maintained on Medium 199 supplemented with $2 \%$ rabbit serum and $0.18 \%$ sodium bicarbonate. Both media contained antibiotics as described for HEK cell cultures.

\section{WI 38 CELLS}

Diploid fibroblasts of the WI38 strain were grown in test tubes using Eagle's basal medium supplemented with $10 \%$ foetal calf serum and $0.06 \%$ sodium bicarbonate. The cells were maintained on Medium 199 supplemented with $2 \%$ foetal calf serum and $0 \cdot 18 \%$ sodium bicarbonate. Both media contained antibiotics as described for HEK cell culture.

\section{INOCULATION AND INVESTIGATION OF CELL} CULTURES

Tubes of each cell-type were prepared in the Public Health Laboratory Service Laboratory, Neasden and transferred to the Virus Laboratory, Institute of Ophthalmology each Monday. Cultures were then incubated stationary at $35^{\circ} \mathrm{C}$ until required. Maintenance medium was replaced immediately before the cells were inoculated unless it had been replaced during the previous 24 hours.

Aliquots of the 2SP transport medium in which specimens had been extracted were inoculated in $0.2 \mathrm{ml}$ amounts into two tubes each of HEK, WI38, and HeLa cell cultures, and these were incubated at $35^{\circ} \mathrm{C}$ on roller drums.

The inoculated tubes of each cell-type were examined daily for the presence of a cytopathic effect (CPE) until they were transferred back to the PHLS Laboratory, Neasden on the Monday following inoculation. Thereafter cultures were examined every two or three days. The isolates obtained in the cell cultures were identified using standard methods. Negative cultures in each cell system were harvested and passed at least once more in the relevant cell culture system. The minimum period for which specimens were cultured in each system was HEK cells 21 days, WI38 cells 21 days, and HeLa cells 28 days.

\section{Results}

One hundred specimens were inoculated into HEK, WI38, and HeLa cells. One specimen was heavily contaminated bacterially and was excluded from the study. From the 99 specimens remaining a total of 31 viruses was isolated (table I).

Twenty-one adenovirus isolates of various serotypes were obtained, 20 in HEK cells, eight in HeLa cells, and four in WI38 cells. Of the 10 herpes simplex viruses isolated, nine were obtained in HEK cells, seven in WI38 cells, and none in HeLa cells.

The serotypes of adenoviruses isolated are shown in table II. Of the seven isolates of adenovirus type 8, six were made in HEK cells and only one in HeLa cells. Adenovirus types 4, 7, and 13 were isolated in HEK cells only. This may reflect differences in sensitivity of HeLa and WI38 cells for these adenovirus serotypes but the number of isolates is too small to allow any definite conclusion on this observation.

The time needed for the detection of virus infection

\begin{tabular}{lllll}
\hline $\begin{array}{l}\text { Type of Virus } \\
\text { Isolated }\end{array}$ & Type of Cell & & $\begin{array}{l}\text { Total } \\
\text { Isolates }\end{array}$ \\
\cline { 2 - 5 } & HEK & WI38 & HeLa & \\
\hline $\begin{array}{l}\text { Adenovirus } \\
\text { Herpes }\end{array}$ & 20 & 4 & 8 & 21 \\
$\begin{array}{l}\text { simplex virus } 9 \\
\text { Total }\end{array}$ & 29 & 11 & 0 & 10 \\
\hline
\end{tabular}

Table I Comparison of sensitivity of HEK cells, HeLa cells, and WI38 cells for the primary isolation of viruses 1

${ }^{1}$ From 99 specimens

\begin{tabular}{lllll}
\hline $\begin{array}{l}\text { Serotype of } \\
\text { Adenovirus }\end{array}$ & \multicolumn{2}{l}{ Type of Cell } & $\begin{array}{l}\text { Total } \\
\text { Isolates }\end{array}$ \\
\cline { 2 - 4 } & HEK & WI38 & HeLa & \\
\hline 3 & 9 & 4 & 7 & 9 \\
4 & 1 & 0 & 0 & 1 \\
7 & 3 & 0 & 0 & 3 \\
8 & 6 & 0 & 1 & 7 \\
13 & 1 & 0 & 0 & 1 \\
Total & 20 & 4 & 8 & 21 \\
\hline
\end{tabular}

Table II Serotypes of adenovirus isolates in HEK cells, Hela cells, and WI38 cells 


\begin{tabular}{llll}
\hline Virus Isolated & \multicolumn{3}{l}{ Type of Cell } \\
\cline { 2 - 4 } & HEK & WI38 & HeLa \\
\hline $\begin{array}{l}\text { Adenovirus type } 3 \\
\begin{array}{l}\text { Herpes simplex } \\
\text { virus }\end{array}\end{array}$ & $6.5(9)^{2}$ & $15.0(4)$ & $14.7(7)$ \\
\hline
\end{tabular}

Table III Mean day to appearance of cytopathic effect on HEK cells, HeLa cells, and WI38 cells

${ }^{1}$ Number of strains isolated

'Six strains isolated in both HEK and WI38 cells

in each cell system is shown in table III. The times shown in this table are slightly overestimated as cultures were not examined daily. The time taken for the detection of a cytopathic effect due to herpes simplex virus was not significantly different in HEK cells from that in WI38 cells (7.3 days and 5.5 days respectively). The detection of adenovirus type 3, however, was significantly earlier in HEK cells than in HeLa and WI38 cells (6.5 days, $14 \cdot 7$ days, and 15.0 days respectively.)

\section{Discussion}

Adenoviruses and herpes simplex virus are the commonest causes of viral conjunctivitis and keratoconjunctivitis reported in the United Kingdom (Jones, Andrews, Henderson, and Schofield, 1957; PHLS, unpublished data, 1973).

Therefore cell cultures used for the study of viral infections of the eye must be particularly sensitive to these two agents.

Hart et al (1965), studying herpetic keratitis, claimed an isolation rate of $89 \%$ using primary rabbit kidney cells and considered this the maximum efficiency they were likely to achieve. White et al (1968) found HeLa cells and baby hamster kidney fibroblast (BHK21) cells satisfactory in a similar study, while Gardner et al (1968) considered that HeLa cells, WI38 cells, and HEP2 cells provided 'optimal' culture conditions for virus isolation in their study of herpetic corneal ulcers. None of these workers discussed the suitability of their culture systems for the isolation of adenovirus.

On the other hand, Ellison et al (1969) used human amnion (HA) cells for the isolation of adenovirus type 3, while Ward et al (1955) obtained satisfactory results with HeLa cells for the isolation of adenovirus types 3 and 4 from the eyes of experimentally infected volunteers. Beale, Doane, and Ormsby (1957) found HA cells superior to HeLa cells for the isolation of adenoviruses from eye infections. Sommerville (1958) found the latter cells unsatisfactory in the study of an outbreak due to adenovirus type 8, a conclusion supported by Bell et al (1969) who found HEK cells and HA cells suitable for the isolation of this virus. None of these workers reported on the suitability of their systems for the isolation of herpes simplex virus and othert serotypes of adenovirus.

In the study reported here we have compared the efficiency of $\mathrm{HeLa}$ cells (a continuous cell line WI38 cells (a semi-continuous cell line), and HER cells (primary cells) for the isolation of viruses from the eye. The results indicate the clear supe $\vec{B}$ iority of HEK cells for this purpose. Using these cells alone, only two of the possible 31 virus iso్ lations would not have been obtained. Howevef in view of possible difficulties in maintaining a supply of HEK cells it would seem advisable to considero alternative cell cultuie systems either alone or ifp combination which would provide an adequate rate of isolation.

The poor sensitivity of HeLa cells and fibroblast cells for herpes simplex virus and adenoviruses respectively would preclude either of these two cen culture systems being used alone in ophthalmic virology. However, it might be expected that in combination they would prove satisfactory? Our results indicate that this may not be the case Taken together, these two cell systems accounte for only $19(61 \%)$ out of 31 possible viral isolations and for only two of the five adenovirus serotypes shown to be present. Although both these cells ar: readily obtainable and easily maintained they $\mathrm{d} \overrightarrow{\mathrm{g}}$ not appear to offer an adequate alternative to HEß cells.

In this study conjunctival swabs were used to collect material for virus culture. A quantitative study by Darougar and colleagues (1972) showed that for the isolation of TRIC agent (Chlamydia) conjunctival swabbing was superior to scraping and caused less conjunctival inflammation. $O B$ the other hand, for isolation of herpes simpley virus, studies suggest that corneal scraping may be superior (Hanna, Jawetz, and Coleman, 1957; Brighto man, Hart, Porter, Readshaw, and Tully, 1964; White. et al, 1968). Information on the relative efficiency of these two methods for the isolation of adenovirus is lacking, and further studies on their comparative usefulness in ophthalmic virology generally are required.

We are grateful to our colleagues at Moorfield and other hospitals for referring their patients; to the members of the External Eye Diseases Clinic Moorfields Eye Hospital for their collection of clinical specimens; to Mr D. F. Halliday, FIMLT for technical assistance; and to Professor B. RO Jones for the encouragement and guidance giver to this work. 
We are indebted to the Research and Development Division of the Department of Health and Social Security for financial support for part of this work.

\section{References}

Beale, A. J., Doane, F., and Ormsby, H. L. (1957). Studies on adenovirus infections of the eye in Toronto. Amer. J. Ophthal., 43, Suppl. (April), 26-31.

Bell, E. J., Martin, K. W., and Ross, C. A. C. (1969) Laboratory diagnosis of epidemic keratoconjunctivitis. J. med. Microbiol., 2, 125-130.

Brightman, V. J. F., Hart, D. R. L., Porter, G. T. J., Readshaw, G. G., and Tully, M. J. (1964). A controlled study of the effectiveness of IDU in the treatment of human herpes simplex keratitis. In Transactions of the Meeting of the Asia-Pacific Academy of Ophthalmology, Melbourne, Australia, 2nd Congress, Vol. 2, edited by G. Serpell. National Press, Melbourne.

Darougar, S., Jones, B. R., Kinnison, J. R., VaughanJackson, J. D., and Dunlop, E. M. C. (1972). Chlamydial infection: advances in the diagnostic isolation of chlamydia, including TRIC agent, from the eye, genital tract and rectum. Brit. J. vener. Dis., 48, 416-420.

Ellison, E. D., Kaufman, H. E., and Little, J. M. (1969). Comparison of methods for the laboratory diagnosis of ocular adenovirus type 3 infection. J. invest. Ophthal., 8, 484-487.

Gardner, P. S., McQuillin, J., Black, M. M., and Richardson, J. (1968). Rapid diagnosis of herpesvirus hominis infections in superficial lesions by immunofluorescent antibody techniques. Brit. med. J., 4, 89-92.

Hanna, L., Jawetz, E., and Coleman, V. R. (1957). The significance of isolating herpes-simplex virus from the eye. Amer. J. Ophthal., 43, Suppl. (April), 126-131.

Hart, D. R. L., Brightman, V. J. F., Readshaw, G. G., Porter, G. T. J., and Tully, M. J. (1965). Treatment of human herpes simplex keratitis with idoxuridine. Arch Ophthal., 73, 623-634.

Jones, B. R., Andrews, B. E., Henderson, W. G., and Schofield, P. B. (1957). The pattern of conjunctivitis at Moorfields during 1956. Trans. ophthal. Soc. U.K., 77, 291-305.

Sommerville, R. G. (1958). Epidemic kerato-conjunctivitisand adenovirus infection. J. Hyg. (Lond.), 56, 101-107.

Ward, T. G., Huebner, R. J., Rowe, W. P., Ryan, R. W., and Bell, J. A. (1955). Production of pharyngoconjunctival fever in human volunteers inoculated with APC viruses. Science, 122, 1086-1087.

Wegman, D. H., Guinee, V. F., and Millian, S. J. (1970). Epidemic keratoconjunctivitis. Amer. J. publ. Hlth, 60, 1230-1237.

White, D. O., Shew, M. A., Howsam, K. G., and Robertson, I. F. (1968). Herpes simplex virus infection of the cornea. Med. J. Aust., 2, 59-63. 